\title{
Economic development and trade outcomes in East African countries: prospects and constraints
}

\section{Romanus Osabohien*}

Department of Economics and Development Studies,

Covenant University,

Ota, Nigeria

and

Centre for Economic Policy and Development Research (CEPDeR),

Covenant University,

Ota, Nigeria

Email: romanus.osabohien@covenantuniversity.edu.ng

${ }^{*}$ Corresponding author

\section{Oluwatoyin Matthew, Busayo Aderounmu and Abigail Godwin}

Department of Economics and Development Studies,

Covenant University,

Ota, Nigeria

Email: oluwatoyin.matthew@covenantuniversity.edu.ng

Email: busayo.aderounmu@covenantuniversity.edu.ng

Email: abigail.godwin@stu.cu.edu.ng

\section{Victoria Okafor}

Department of Economics and Development Studies,

Covenant University,

Ota, Nigeria

and

Centre for Economic Policy and Development Research (CEPDeR),

Covenant University,

Ota, Nigeria

Email: victoria.okafor@covenantuniversity.edu.ng

Abstract: This study employed a panel data analysis from selected East African countries, with the use of fixed and random effects model which was tested using Hausman specification test. The results from the study showed that; trade agreement and foreign direct investment (FDI) have a significant positive effect on East African economy, while trade openness exerts a negative effect as a result of low productivity. Therefore, the study recommended that the government of East African countries should embrace and develop policies 
in promoting the continental trade agreement and economic integration, in order to raise the level of productivity within the region and the sub-region for sustainable economic development.

Keywords: East Africa; economic development; economic integration; trade openness; trade outcomes.

Reference to this paper should be made as follows: Osabohien, R., Matthew, O., Aderounmu, B., Godwin, A. and Okafor, V. (2021) 'Economic development and trade outcomes in East African countries: prospects and constraints', Int. J. Trade and Global Markets, Vol. 14, No. 1, pp.1-18.

Biographical notes: Romanus Osabohien is a PhD Student and a Lecturer in the Department of Economics and Development Studies as well as a Research Associate at the Centre for Economic Policy and Development Research (CEPDeR), Covenant University, Ota, Nigeria. He obtained his BSc in Economics from Ambrose Alli University, Ekpoma, Nigeria (2011) and MSc in Economics from Covenant University, Ota, Nigeria (2017). His main research focus is on agricultural economics/food security and development economics. He has attended and presented research papers in both international and local conferences/workshops and has also published peer-reviewed articles in rated journals.

Oluwatoyin Matthew $(\mathrm{PhD})$, is an astute Lecturer and Researcher. Her $\mathrm{PhD}$ Thesis titled 'Trade Liberalization, Institutions and Economic Growth in selected sub-Saharan countries was completed in Covenant University, Ota, Nigeria in 2013. She is currently a Senior Lecturer in the Department of Economics and Development Studies, Covenant University, Ota, Nigeria. She has published widely in reputable local and international Scopus indexed journals, and attended several international conferences and workshops. Her research interest include; energy economics, development economics, agricultural economics, international economics and political economy.

Busayo Aderounmu $(\mathrm{PhD})$ is currently a Lecturer in the Department of Economics and Development Studies, College of Business and Social Science, Covenant University, Ota, Ogun State, Nigeria. She obtained her BSc (Ed.), $\mathrm{MSc}$, and $\mathrm{PhD}$ in Economics from the great citadel of learning-Obafemi Awolowo University, Ife, Nigeria in 2008, 2012 and 2017, respectively. She has published papers in reputable journals and presented papers in conferences. Her areas of research interest include development economics, gender economics, labour and health economics.

Abigail Godwin is a Researcher and a Data Analyst who obtained her BSc in Economics from Babcock University, Ilishan-remo, Ogun State, Nigeria (2014); and her MSc in Economics from Covenant University, Ota, Nigeria (2018). She has been privilege to publish papers in reputable International Scopus Indexed Journals and attended a couple of conferences and seminars. Her research interest includes: industrial economics, agricultural economics and development economics.

Victoria Okafor is a $\mathrm{PhD}$ student and a Lecturer in the Department of Economics and Development Studies, Covenant University, Ota, Nigeria. She is an upcoming researcher with research interest in Financial economics, monetary economics, gender and development economics. She is also a 
research fellow at the Centre for Economic Policy and Development Research (CEPDeR) and French Institute for Research in Africa, Nigeria (IFRANigeria).

\section{Introduction}

For several years, there has been a movement towards regional economic integration throughout the world. A regional integration arrangement can be regarded as a preferential (usually reciprocal) agreement among countries that reduces barriers to economic and non-economic transactions (UNECA, 2004). It is the unification of different economies or countries in order to promote and facilitate the free movement of goods and services within themselves. All regional integration agreements have the objective of reducing or eliminating barriers between their members. However, they also exhibit a wide range of variation. In terms of depth, their variation depends on the level of integration undertaken by member countries (Hailu, 2014; Mold and Mukwaya, 2016).

Economic integration in Africa has seemed to be far-fetched, as efforts geared towards achieving integration has been ineffective as can be seen in the poor economic and political performance of the continent compared to other economies like the European Union. According to Mistry (2000), integration in the African economies has not been seen as a way for the economies in Africa to cope with the rapidly globalising world which accompanies increasing competitiveness. Since the independence of African economies from the colonial rule, some African economies despite the endowment of natural resources have still been economically unviable for decades because the economies are making more effort at remaining politically separated and convincing themselves of economic fusion at arm's length (Saygili et al., 2018; Wamboye et al., 2013).

The East African Community (EAC) had more mobility of goods, labour and capital as the community engaged in a common currency, common postal and telecommunication union, a common airline and a common secretariat. The greatest period of growth in the African market was between the 1940s and 1950s was also the period of increasing frictions as a result of independence bringing about territorial awareness to the individual states (Wamboye et al., 2016).

The African continent, like other developing continents and regions has suffered foreign exchange gaps and savings which can be seen as the reason for low capital accumulation and dawdling development and economic integration (Matthew et al., 2019a, 2019c; Osabuohien et al., 2018; Wamboye et al., 2013). Ejemeyovwi et al. (2018), Sachs (2005) suggested that there should be reasonable and sustainable flow aid that is necessary for countries to surpass the take-off into self-sustained growth through the development of human capital and strong institutional framework. Other scholars proposed that debt relief programs are necessary as an additional policy tool for tackling growth and development problems in developing countries (Afolayan et al., 2019; Barone et al., 2005). However, the proponents of free market system are of the opinion that integrating of Africa into the global financial system is vital in order to promote entrance of Foreign direct investment (FDI) and other portfolio type investments (Ajayi and Ndikumana, 2015; Matthew et al., 2019b). 
Regional integration has been explained by Hamad (2016) as the process by which two or more countries agree together to achieve peace, stability and wealth as one. On the other hand, regional economic integration explains economic integration as being limited to a particular region. That is, regional economic integration is a form of agreement where countries in the same region defined by geography, come together to reduce and/or eliminate trade tariffs and non-trade tariffs to facilitate mobility of goods and services as well as factors of production. Carbaugh (2004) defined economic integration as the elimination of restrictions to international trade, payments and factor mobility.

With the lessons learnt from the collapse of EAC in 1977, the goal of the new EAC is to become a monetary union. This will be an incremental development from the phases of the common market (kicked off in 2005), customs union (took off in 2005), federation (achieved in 2016) and finally single currency (which started in 2018). The custom union that commenced in 2005 as stipulated was executed gradually to a free trade regime in 2010. The EAC common market commenced July 2010 and the member states embarked on the creation of East African monetary union (Newman and Clarke, 2009). According to Hamad (2016), the EAC integrates through the neo-functionalism strategy as the operational techniques of EAC are centred around a market-oriented and people-centred organisation. Neo-functionalism being a theory that was first developed by Ernst Haas explains the process of regional integration proceeding from spill-over process where the aim of achieving integration in other sector leads to the integration of an individual sector (Matthew et al., 2018b; Collins, 1998).

Thus, this study sets out to examine the prospects and constraints of the East African community's trade agreement vis-a-vis the continental economic integration of Africa. The study comprises of five sections; Section 2 presents some insights from empirical literature, stylised facts and theoretical framework. Section 3 unveils the method engaged in the study; Section 4 discusses the empirical analysis, the results and findings of the study; Section 5 concludes the study by recommending policies that will help turn around the issues associated the East African trade agreement in the bid to have smooth regional trade integration.

\section{Empirical literature and stylised facts}

\subsection{Empirical literature}

Integration of economies is inevitably a medium of achieving the required level of development as some economists have the opinion that economic integration of developed countries culminate in the long-term growth (Rivera-Batiz and Romer, 1991). This could probably be one of the reasons why there is a disparity in the growth rates of developed and developing economies. The initiatives on economic integration in Africa dates back to 1910 with the establishment of South African Customs Union as well as East African Community (EAC) in 1919 which consisted of Kenya, Uganda and Tanzania (Geda and Kebret, 2008). However, after the actualisation of independence from the colonial masters, the EAC set out to form a customs union in 1967 which crumbled in 1977 due to political reasons. The re-established EAC aims beyond economic integration to common money market and majorly political integration (Castro et al., 2004). 
The promotion of regional integration in Africa has been plagued with some challenges which include; the challenge of how to promote inter-and-intra-regional trade in Africa. "A number of factors have contributed to the poor (inter/intra) African trade performance: Firstly, most countries in the region basically produce raw materials, which are less competitive in international markets. Sometimes, they are raw materials for which there is virtually no demand elsewhere in Africa" (Esterhuysen, 1978). Secondly, many African countries have not diversified their products hence "few commodities often make up the bulk of their exports" (Mutume, 2002). For instance, petroleum products account for more than $90 \%$ of Angola's export to other countries in Africa. Likewise, fresh fish constitutes nearly $98 \%$ of such exports for Seychelles. Thirdly, many African countries are still "grappling to undo a legacy dominated by trade with their former colonial rulers rather than with each other". For example, Senegal is the Gambia's neighbour, trade between these two countries is negligible. France is Senegal's biggest trading partner, while the Gambia trades largely with the United Kingdom (UK). Furthermore, because of these "hindrances to trade within Africa, exports from Tunisia and Cameroon often find their way to French warehouses before being redirected to each other's market shelves".

The second challenge of promoting regional integration in Africa concerns the low level of inefficient or inadequate infrastructures, particularly transport and communications on the continent. Transportation of goods is very costly, for example, the freight costs for imports to "landlocked African countries are more than twice as high as in Asia". Furthermore, it is not out of place to note that travelling from one African country to another by air is more difficult and in some cases, this has meant that one has to "travel via Geneva or Paris." The problem is even intensified in relation to visa acquisition formalities. For example, African entrepreneurs "frequently need to wait for 6-8 weeks to get visas to visit other African countries while citizens of the UK or France can travel to many African countries and obtain visa on arrival" (Harsch, 2002; Tiruneh et al., 2016; Goyal et al., 2018; Osabohien et al., 2018).

Statistically, Africa has the lowest "telephone density in the world yet the highest telephone charges, and three times the rate of faults per line as in other developing regions" (Kawonishe, 2001). In its report, the World Bank (2008) noted for every 100 people in Africa, there are 1.2 telephone lines - the lowest rate in the world (2016) telephone calls between African countries can be 50-100 times more expensive than they are within North America" (Mutume, 2002). Ngepah and Udeagha (2018) using gravity model examined Africa regional trade agreements and intra-Africa trade using for 53 African countries from 1995-2015. The result of the Eicker-White robust covariance Poisson pseudo-maximum likelihood method showed that trade can be enhanced through regional trade agreements. The results showed that distance inhibits trade while GDPs of two trading countries enhances trade.

In line with Ngepah and Udeagha (2018), Mold and Mukwaya (2016) in their study on the effect of the regional trade agreement on manufacturing exports also used gravity model on data spanning 1990 to 2015 for 45 African countries. The result of the Poisson pseudo-maximum likelihood estimator discovered that within 12 years of forming regional trade agreement, it caused about $72 \%$ increase in manufacturing sector between members although there is weak evidence exist in literature thereby informing that regional integration is not sufficient enough to increase manufacturing export. 
The study, however, focused on manufacturing export. Hailu (2014) examined the challenges and prospect of regional economic integration in Africa and found that trade openness and FDI has helped most African countries to develop since the last two decades.

Akin to Hailu (2014), Saygili et al. (2018) validated the study by using four different scenarios estimated the costs and benefits of tariff reduction in intra-African trade. The results showed the existence of long-run welfare gains, output expansion, and an increase in employment as well as intra-Africa trade growth. In the short run, there is however, the tariff revenue losses and unequal distribution of adjustment costs that may delay the process of negotiation. Mevel and Karingi (2012) examined the constraints on intra-African trade using modelling international relationships in applied general equilibrium (MIRAGE) computable general equilibrium model. The result of their findings from 27 countries/regions (16 African countries and 6 regions) showed that continental free trade area would increase trade within Africa while the elimination of tariff barriers is not adequate for doubling by 2022 the share of intra-Africa trade.

However, the adoption of non-tariff measures like reducing customs procedures and port handling can help in attaining the goal. The efforts at making the world a global market has been into play since trade originated. The efforts in this 21 st century however, have got more attention as it has now been recognised by the United Nations that one of the means of attaining sustainable development is through global partnership. Integration of economies is inevitably a medium of achieving the goal of development as some economists have the opinion that economic integration of developed economies culminates into long term growth of these economies (Rivera-Batiz and Romer, 1991). This could probably be one of the reasons for growth rate disparity between developed and developing economies.

Economic integration in Africa has seemed far-fetched as efforts geared towards achieving integration has been ineffective which can be seen in the poor economic and political performance of the continent compared to other economies like the European Union. According to Mistry (2000), integration in African economies has not been seen as a way for the economies in Africa to cope with the rapidly globalising world which accompanies increasing competitiveness. Since the independence of African economies from the colonial rule, some African economies despite the endowment of natural resources have still been economically unviable for decades because the economies are making more effort at remaining politically separated and convincing themselves of economic fusion at arm's length (Mistry, 2000).

The East African Community (EAC) is said to be rich in history as it was first established by the colonials in 1919 as a customs union which involved just Kenya and Uganda until Tanzania joined in 1927 to make common market and economic integration in East Africa was believed to be more advanced in the region before independence (Nye, 1963). The EAC had more mobility of goods, labour and capital as the community engaged in a common currency, common postal and telecommunication union, a common airline and a common secretariat. The greatest period of growth in the African market was between the 1940s and 1950s was also the period of increasing frictions as a result of independence bringing about territorial awareness to the individual states. 
Table 1 Intra-trade and extra-trade of country groups by product, annual (all products)

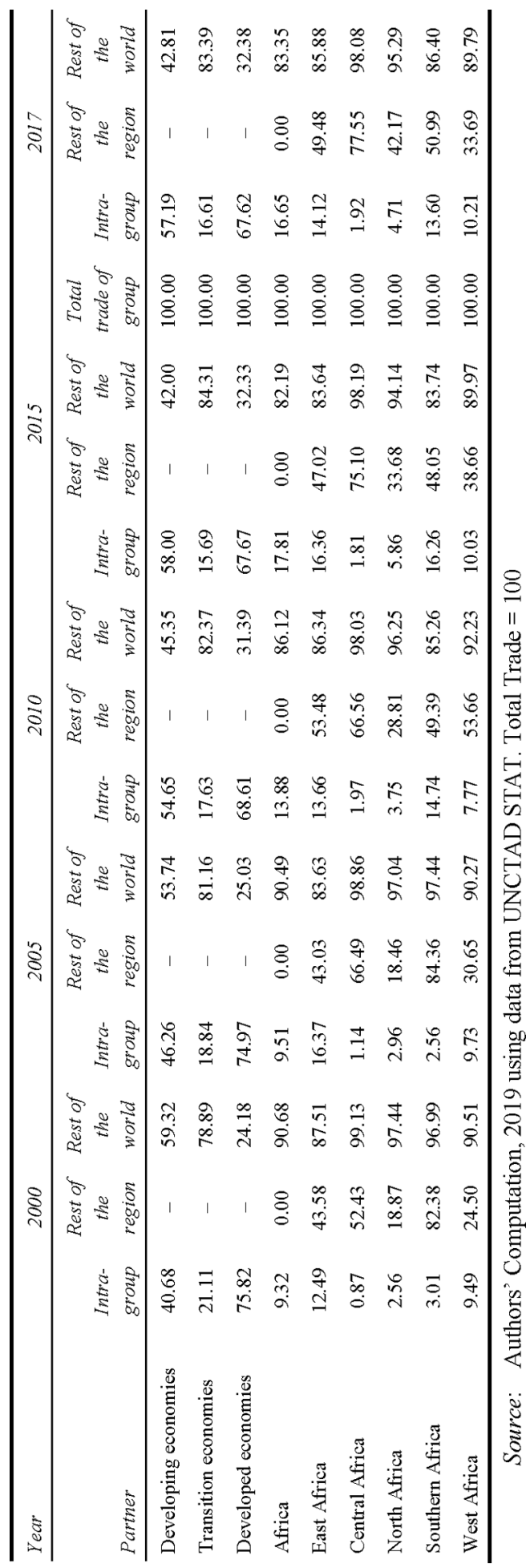


The new EAC, although not yet a federation was established officially on 7 July, 2000, consisting of six member countries; Kenya, Uganda, Tanzania, Rwanda, Burundi, and South Sudan with South Sudan is the newest member state as it joined EAC in March 2016 (Hamad, 2016). Regional Integration has been explained by Hamad (2016) as the process by which two or more nation-states agree together to achieve peace, stability and wealth as one. Whereas, regional economic integration explains economic integration with the limit to a particular region. That is, regional economic integration is a form of agreement nation-states in the same region defined by geography to reduce and/or eliminate trade tariffs and non-trade tariffs to facilitate mobility of goods and services as well as factors of production. Carbaugh (2004) defined economic integration as the elimination of restrictions to international trade, payments and factor mobility.

With the lessons learnt from the collapse of EAC in 1977, the goal of the new EAC is to become a monetary union. This will be an incremental development from the phases of the common market (kicked off 2005), Customs Union (2005), Federation (2016) and finally single currency (2018). The custom union that commenced in 2005 as stipulated was executed gradually to a free trade regime in 2010. The EAC common market commenced July 2010 and the member states embarked on the creation of East African monetary union (Clarke, 2009). That EAC has what it takes to actualise the singles currency federation is still under debate. According to Hamad (2016), the EAC integrates through the neo-functionalism strategy as the operational techniques of EAC are centred around a market-oriented and people-centred organisation. Neo-functionalism being a theory that was first developed by Ernst Haas explains the process of regional integration proceeding from spill-over process where the aim of achieving integration in other sector leads to the integration of an individual sector (Collins, 1998; Goyal et al., 2016).

\subsection{Stylised facts}

Table 1 shows the annual intra and extra group distribution of product by region over some period. Statistics show that there is a steady increase in intra-group trade in developing economies over the years from 40.68 in 2000 to 58 in 2015 which however declined to 57.19 in 2017. Trade with the rest of the world in developing economies took a reverse order from intra-group trade as statistics show that there was a consistent decline in extra-trade of the group from 59.32 in 2000 to 42 in 2015, which was followed by a slight increase to 42.81 in 2017 .

The trend of trade in developed economies show that there is a consistent decline in intra-group trade while trade with the rest of the world consistently increases over the years from 24.18 to 32.38 in 2000 and 2017 respectively. While trade with all member of the group in transition economies experience a downward decline until 2015, extra-trade of the group continuously increased until 2015 before a slight decline from 84.31 in 2015 to 83.39 in 2017. Intra-trade group in African increased and almost doubled by 2015. Statistics show that intra-trade group was 9.32 in 2000 which increased to 17.81 in 2015 before a slight decline in 2017 to 16.65 . This is a landmark improvement in trade with member countries which may be attributed to several measures put in place by the government to enhance trade within the region.

The descriptive statistics results in Table 1 show that East Africa had a steady increase in intra-group trade throughout the years of study. In 2000, West Africa was the 
second highest region trading with all members of the group followed by Southern Africa and North Africa. Although all regions experienced an increase in the volume of trade, by 2010, Southern Africa became the second highest intra-trade region followed by West Africa. Figure 1 show that developing economies trade with other members of the group. The figure also shows that there was a decline in trade between 2010 and 2011, which was followed by an increase until 2014 before the sight decline. African countries in the likes of Central Africa, East Africa, North Africa, and Southern Africa follow similar trade trend over the years.

Figure 1 Africa's intra-group trade (see online version for colours)

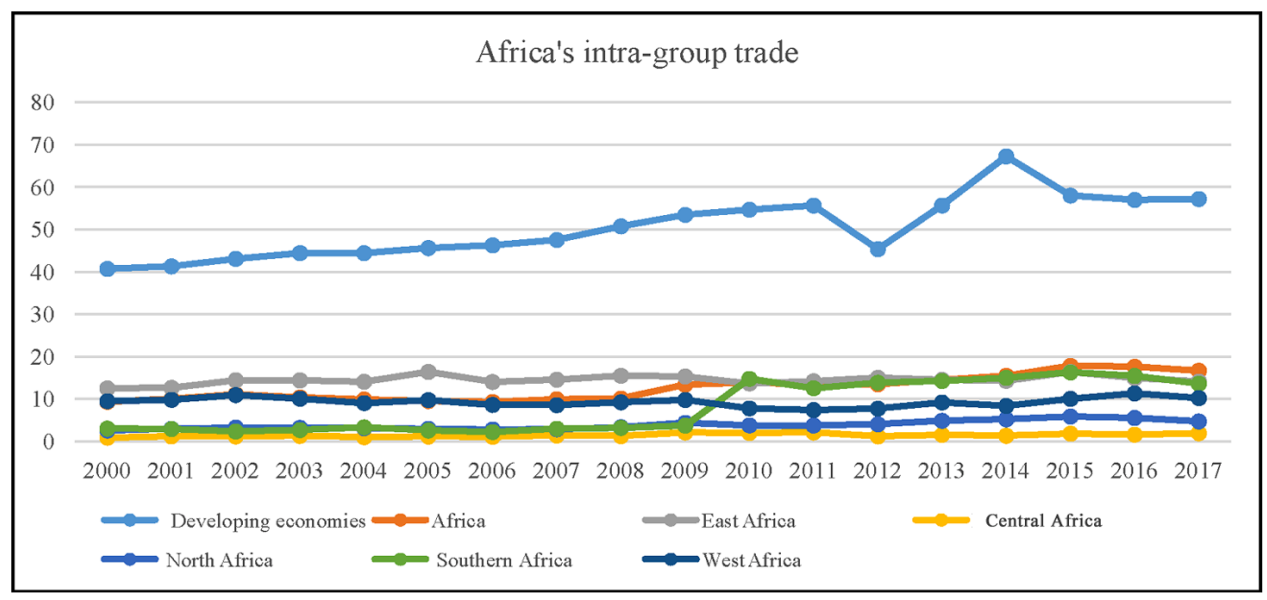

Source: Authors' Compilation, 2019

\subsection{Theoretical framework}

The theoretical premise of this study is based on the theory of integration known as intergovernmentalism. This theory was initially proposed by Stanley Hoffmann and refined by Andrew Moravcsik. According to Abbiss and Laursen (2008), the Andrew Moravscik theory of Inter-governmentalism has become an important reference point for recent studies on integration. The theory of inter-governmentalism suggests that government control the level and speed of integration. Hoffman argued that every international system owes its inner logic and it is unfolding to the diversity of domestic determinants, geo-historical situations and outside aims among its units. The diversity sets a limit to the degree to which the 'spill-over' process can function. "It restricts the domain in which the logic of functional integration operates to the area of welfare". He advanced the suggestion that "in areas of key importance to the national interest, nations prefer the certainty, or the self-controlled uncertainty, of national self-reliance, to the uncontrolled uncertainty of integration" (Hoffman, 1966).

Moravcsik (2006) in advancing liberal inter-governmentalism argues that integration goes as far as member states want it to go and European institutions exist due to the deliberate will of member states to satisfy their interests and are instruments for achieving member states' objectives. For liberal inter-governmentalists, the member states of a regional integration arrangement (for instance, EU member states) are unitary rational actors that are in control of the process of integration and they believe that the 
institutions do not play an important role in big decisions. Institutionalists criticise inter-governmentalists for the latter is failure to attribute an important role for institutions. This means that in spite of the fact that a country is a member of an organisation, she still can take some decisions on her own within the economy without necessarily relying on the organisation entirely.

\section{Methodology}

\subsection{Model specification}

The model specification provides a general view of the basic variables utilised during the analysis. The functional form of the model is given as:

$$
\mathrm{HDI}_{i t}=f\left(\mathrm{FDI}_{i t}, \mathrm{GFCF}_{i t}, \mathrm{TAG}_{i t}, \mathrm{TOP}_{i t}\right)
$$

Given that, there is an assumption of linear relationship between the dependent and independent variables, the explicit form of the model seen below as:

$$
\mathrm{HDI}_{i t}=\beta_{0}+\beta_{1} \mathrm{FDI}_{i t}+\beta_{2} \mathrm{GFCF}_{i t}+\beta_{3} \mathrm{TAG}_{i t}+\beta_{4} \mathrm{TOP}_{i t}+\mu_{i t}
$$

where $\mathrm{HDI}_{\mathrm{i} t}$ is human development indicator as a measure for economic development of country $i$ at time $t$, this is the dependent variable. FDI $_{i t}$ is FDI as a measure of the foreign direct inflows of country $i$ at time $t$. GFCF is a measure of gross fixed capital formation of country $i$ at time $t$. TAG $i t$ is a measure of a trade agreement of country $i$ at time $t$. $\mathrm{TOP}_{i t}$ is a measure of trade openness of country $i$ at time $t$.

\subsection{Fixed and random effect model}

The specified empirical model was estimated using the fixed and random effect model as used in Osuma et al. (2018). This study explains these two common panel data estimation techniques. The panel data, which combines both time series and cross-sectional data, is estimated using a fixed effect or random effect model.

$$
\begin{aligned}
& y_{i t}=X_{i t}^{\prime} \beta+\varepsilon_{i t} \\
& \varepsilon_{i t}=v_{i t}+u_{i t}
\end{aligned}
$$

In the fixed effect model, the $u_{i}$ are treated as $\mathrm{n}$ constants specific to each unit of observation. The least squares dummy variable (LSDV) estimator gives the fixed effect and $\hat{\beta}_{\mathrm{FE}}$ is always consistent, but not efficient.

$$
y_{i t}=\alpha_{i}+X_{i t}^{\prime} \beta+v_{i t}
$$

In the random effect model, the $u_{i}$ are treated as independently disturbed random variables with $u_{i} \sim i i d\left(\mu, \sigma_{u}^{2}\right)$. The feasible generalised least square (FGLS) estimator gives the random effect, and $\hat{\beta_{\mathrm{RE}}}$ is consistent and efficient if $E\left(u_{i} \mid x_{i t}\right)=0$.

$$
y_{i t}=\alpha_{i}+X_{i t}^{\prime} \beta+\left(v_{i t}+u_{i t}\right)
$$

To test if the random effect model is better than the fixed effect model, the Haussmann test was carried out. 


$$
H_{0}: \beta_{\mathrm{FE}}-\beta_{\mathrm{RE}}=0 ; H_{1}: \beta_{\mathrm{FE}}-\beta_{\mathrm{RE}} \neq 0
$$

If the Hausman test rejects the null hypothesis, it implies that the fixed effect remains consistent while random effect model is inconsistent, meaning that the fixed effect model is preferred. On the other hand, if the Hausman test rejects the alternative hypothesis, it implies that fixed effect and random effect are both consistent and random effect is efficient, implying that the random effect model is preferred.

\subsection{Data source}

This study used panel data for a period of 28 years (1990-2017) from seven East African countries out of twelve East African countries due to the availability of data. The data was sourced from world development indicators (WDI). The variables include; human development index proxy for economic development, FDI, gross fixed capital formation, trade agreement and trade openness, as presented in Table 2.

Table 2 Variable descriptions

\begin{tabular}{|c|c|c|c|c|}
\hline Data & Identifier & Source & Definition & Measurement \\
\hline $\begin{array}{l}\text { Human } \\
\text { development index } \\
\text { proxy for } \\
\text { economic } \\
\text { development }\end{array}$ & HDI & HDI & $\begin{array}{l}\text { The Human Development Index provides a } \\
\text { composite measure of development using } \\
\text { metrics of life expectancy, literacy, educational } \\
\text { enrolment and gross domestic product (GDP) } \\
\text { per capita to determine economic development } \\
\text { (UN, 2018) }\end{array}$ & $a, b, c, d$ \\
\hline $\begin{array}{l}\text { Foreign direct } \\
\text { investment }\end{array}$ & FDI & WDI & Foreign direct investment, net inflows & $\%$ GDP \\
\hline $\begin{array}{l}\text { Gross fixed capital } \\
\text { formation }\end{array}$ & GFCF & WDI & $\begin{array}{l}\text { Gross fixed capital formation is essentially a net } \\
\text { investment. It is a component of the expenditure } \\
\text { method of calculating GDP }\end{array}$ & $\%$ GDP \\
\hline Trade agreement & TAG & WDI & Taxes on exports ( $\%$ of tax revenue) & \\
\hline Trade openness & TOP & WDI & $\begin{array}{l}\text { Trade openness refers to the inward or outward } \\
\text { orientation of a given economy. The inward one } \\
\text { means the economies that overlook or unable to } \\
\text { take advantage of the opportunities to trade with } \\
\text { other countries, while the outward orientation is } \\
\text { referred to as when the economy takes full } \\
\text { advantage of trade opportunities. }\end{array}$ & $\begin{array}{l}\text { (Export- } \\
\text { import)/GDP }\end{array}$ \\
\hline
\end{tabular}

$\mathrm{a}=$ life expectancy at birth (to assess long and healthy life); $\mathrm{b}=$ adult literacy (percentage of population over 15 years who can read and write); $\mathrm{c}=$ educational enrolment rates (percentage of population in relevant age cohort enrolled in primary secondary and tertiary education); $\mathrm{d}=$ gross domestic product (GDP) per capita (to assess standard of living).

Source: Authors' Compilation, 2019

\section{Results}

The results presented in this section of the study are in two folds: the descriptive or summary statistics and the econometric results. The descriptive statistics gives summary 
of the variables that were engaged in the study, while the econometric aspect of the result presents the estimates obtained from the random and fixed effects regression model.

\subsection{Descriptive statistics}

The features of the variables in this study are been examined through the descriptive analysis which gives the summary of the variables and their measurement. This subsection indicates the statistical analysis of variables in the study - human development index (HDI), FDI, trade agreement (TAG) and trade openness (TOP). It also indicates the mean which is referred to as the sum of all the values in the data group divided by the total number of the values, median is the middle value of each variable in the dataset, standard deviation which is the positive square root of the variance, minimum value which is the lowest number in a set of data, maximum value which is the highest number in the set of data and range which is the difference between the highest and the lowest number in the data, skewness which shows the degree of asymmetry of the distribution and this could be negatively or positively skewed. Looking at the kurtosis which measures the degree to which the frequency distribution is focused about its mean, it could be mesokurtic (when the kurtosis coefficient is $=3$, platykurtic (when the kurtosis coefficient is <3) and leptokurtic (when the kurtosis coefficient is $>3$ ) as presented in Table 3.

Table 3 Summary statistics of the variables

\begin{tabular}{lccccc}
\hline Diagnostic & $\begin{array}{c}\text { Human } \\
\text { development }\end{array}$ & $\begin{array}{c}\text { Foreign direct } \\
\text { investment }\end{array}$ & $\begin{array}{c}\text { Gross fixed capital } \\
\text { formation }\end{array}$ & Trade agreement & $\begin{array}{c}\text { Trade } \\
\text { Openness }\end{array}$ \\
\hline Mean & 0.46 & -0.056 & 19.85 & 0.01 & 325,353 \\
Minimum & 0.19 & -0.61 & 2.00 & -0.01 & $-2,254,311$ \\
Maximum & 0.79 & 0.06 & 43.05 & 0.09 & $7,166,385$ \\
Std. Dev. & 0.13 & 0.01 & 6.57 & 0.02 & $1,393,424$ \\
Skewness & 0.49 & 2.30 & 0.27 & 1.89 & 3.58 \\
(probability) & $(0.00)$ & $(0.00)$ & $(0.12)$ & $(0.00)$ & $(0.00)$ \\
Kurtosis & 3.25 & 6.72 & 3.91 & 7.05 & 15.83 \\
(probability) & $(0.36)$ & $(0.00)$ & $(0.03)$ & $(0.00)$ & $(0.00)$ \\
Observations & 196 & 196 & 196 & 196 & 196 \\
\hline
\end{tabular}

Source: Authors' Computation, 2019

Table 3 presents the statistical summary of each variable used in this study. Human development index (HDI) had an average value of 0.46 and it ranged between -0.19 to 0.79 during the period of study. The result also showed the dispersion of Human Development Index around the mean value was 0.132 . The skewness value of 0.49 , which is below the threshold of zero indicated that the Human development index is negatively skewed. The kurtosis coefficient $>3$, this indicates that the Human development index is leptokurtic. The normality of the series was tested by skewness/kurtosis normality test; the null hypothesis of this test states that the series are normally distributed but the $p$-value of the test showing $0.36 \%$, which is greater than the $5 \%$ significance level, revealed that HDI is normally distributed. 
The average of FDI during the study period is 0.06 and it ranged between -0.61 to 0.06; the result also disclosed the dispersion of the FDI around the mean value is 0.0148 ; this is an indication that the series sparingly spread around the mean, the FDI of the sampled firms over the examined year clustered around the mean. The skewness value of 2.304463 which is above the threshold of zero indicated that FDI is positively skewed. The kurtosis coefficient $>3$ indicates that FDI is leptokurtic. The normality of the series was tested by skewness/kurtosis normality test; the null hypothesis of this test states that the series are normally distributed but the $p$-value of the test showing $0 \%$, which is lower than the 5\% significance level, revealed that FDI is not normally distributed.

Gross fixed capital formation (GFCF) on the hand had an average of 19.85, which ranged between 2.00 and 43.05. The result also showed the dispersion of gross fixed capital formation around the mean value was 6.7. The skewness value of 0.267 is above the threshold of zero, this indicates that GFCF is positively skewed. The kurtosis coefficient $>3$ indicates that board nationality is leptokurtic. The normality of the series was tested by skewness/kurtosis normality test; the null hypothesis of this test states that the series are normally distributed but the p-value of the test showing $0.12 \%$, which is higher than the 5\% significance level; this reveals that GFCF is normally distributed.

The average of trade agreement (TA) during the years under review is 0.016 and it ranges from -0.01 to 0.911 . The result also revealed the dispersion of trade agreement around the mean value is 0.01 ; this is an indication that the series is spread sparingly around the mean, the TA of the sampled firms over the examined year clustered around the mean. The skewness result of -1.89 , which is above the threshold of 0 shows that TA is positively skewed, this is also reflected in the kurtosis which showed a result of 7.05 in excess of the threshold of 3 means. This implies that the series is leptokurtic; the null hypothesis of this test states that the series are distributed normally but the $p$-value of the test showing $0 \%$, which is lesser than the $5 \%$ significance level, revealed that board size (BS) is not normally distributed. Trade openness (TOP) had an average value of $3,253,534$ and it ranged between $-2,254,311$ and 7,166,385 during the period of study. The result also showed that the dispersion of trade openness around the mean value was $1,393,424$. The skewness value of 3.58 is above the threshold of zero, this indicates that TOP was positively skewed. The kurtosis coefficient $>3$ indicates that trade openness is leptokurtic. The normality of the series was tested by skewness/kurtosis normality test; the null hypothesis of this test states that the series are normally distributed but the $p$-value of the test showing $0 \%$ is lesser than the $5 \%$ significance level, this indicates that (TOP) is normally distributed.

\subsection{Econometric result}

The econometric result from the fixed and random effects regression model for the sample of selected East African countries (due to the availability of data) between 1990 and 2017 as shown in Table 4. The table contains the estimated parameter and the $t$-statistics obtained from the regression of equation (2), using the human development index (HDI) as a proxy for economic development (dependent variable). This study made use of the random effect model of estimation, the Hausman test was carried out to decide between the fixed effect model and random effect model, based on the probability value of the Hausman test, the random effect model was found to be more suitable.

From the results obtained, a $1 \%$ increase in FDI will lead to approximately $1 \%, 3 \%$ and $2 \%$ respectively increase in the economic development of East African countries. 
The implication of this is that FDI and foreigners are required to boost the economic development of any economy. This finding supports the assertion of Wamboye et al. (2013). Wamboye et al. (2016) opined that proponents of the free market system have strongly pushed for integrating Africa into the global financial system in order to attract FDI and other portfolio-type investments necessary for the stimulation of local investment for the desired level of economic development. Also, to achieve sustainable and inclusive economic development, local investment in micro, small and medium enterprises (MSMEs), infrastructure and other key areas of the economy should be made to attract (Goyal et al., 2016).

Table 4 Econometric results

\begin{tabular}{lcccccccc}
\hline Method & \multicolumn{2}{c}{ POOLED OLS } & \multicolumn{3}{c}{ Fixed effects } & \multicolumn{3}{c}{ Random effects } \\
\hline Variables & Coeff. & T-stat & Probability & Coeff. & t-stat & P-value & Coeff. & $Z$-stat \\
\hline Foreign direct investment & 0.01 & $2.45^{*}$ & $0.01^{*}$ & 0.03 & 0.19 & 0.84 & 0.02 & 0.23 \\
$\begin{array}{l}\text { Gross fixed capital } \\
\text { formation }\end{array}$ & 0.09 & $5.75^{*}$ & $0.00^{*}$ & 0.03 & $3.35^{*}$ & $0.00^{*}$ & 0.03 & 3.43 \\
Trade agreement & 0.05 & -0.83 & 0.40 & 0.02 & $5.31^{*}$ & $0.00^{*}$ & 0.02 & 5.34 \\
Trade openness & -0.02 & $2.48^{*}$ & $0.01^{*}$ & -0.09 & -1.78 & 0.07 & -0.09 & -1.76 \\
Constant & 0.26 & $8.37^{*}$ & $0.000^{*}$ & 0.36 & $23.09^{* *}$ & $0.00^{*}$ & 0.36 & 6.11 \\
& $R$-squared $=0.35$ & \multicolumn{2}{c}{$R$-squared $=0.39$} & & $R$-squared $=0.39$
\end{tabular}

Hausman Test: $\mathrm{Chi}^{2}{ }_{(1)}=0.03$, Prob $>\mathrm{chi}^{2}=0.8645$

Breusch and Pagan Lagrangian multiplier: $\mathrm{Chi}^{2}{ }_{(1)}=1333.20$, Prob $>\mathrm{chi}^{2}=0.0000$

Breusch-Pagan/Cook-Weisberg test for heteroscedasticity: $\mathrm{Chi}^{2}{ }_{(1)}=0.48$, Prob $>\mathrm{chi}^{2}=0.4895$

Wooldridge test: $F_{(1,6)}=8326.351$, Prob $>F=0.0000$

$*$ and $* *$ means that coefficients are statistically significant of significance at $1 \%$ and $5 \%$ level respectively.

Source: Authors' Computation, 2019

Similarly, a $1 \%$ increase in gross fixed capital formation will lead to approximately $9 \%$ and $3 \%$ respective increase in economic development meaning that investment and capital inflows, while trade agreement leads to $5 \%$ and $9 \%$ respectively increase in economic development. On the hand, trade openness was observed to have a negative effect on economic development of East African economies, this implies that East African region; though, open to trade, the rate of import is greater than the rate of export, thus leading to dumping. It can inferred that the more African countries are opened to trade, the more vulnerable they become to dumping due to the low level of productivity leading net import (export greater than import, deficit terms of trade).

As pointed out earlier, in order to determine the most appropriate method of estimating the regression model among pooled OLS, fixed effects and random effects results as presented in Table 5, the Hausman test was carried out; and based on the result of the test as shown in Table 4 which stated that pooled OLS is the most appropriate estimator. The result of the Hausman test with the p-value of 0.86 , indicating $86 \%$ is higher than the $5 \%$ level of significance chosen for the study reveals that pooled OLS is 
the most appropriate estimator according to its null hypothesis which states that there is presence of unsystematic difference in the model coefficients; thus, the study do reject the null hypothesis.

Although, the Hausman test result revealed the appropriateness of random effects the confirmation of the result of the Hausman test was carried out using the Breusch-Pagan Lagrangian multiplier test. This test helps to decide the most appropriate model between the random effects and pooled OLS regression. The null hypothesis of this test is that no significant difference across units (that is no panel effect). The results of the Breausch-Pagan Lagrangian multiplier test showed a $p$-value of 0.0000 , which is less than the significance level of $5 \%$. This is an indication that random effect is a good estimator of the model; therefore, the study rejects the null hypothesis, which implies that random effect is the most appropriate estimator for the model.

To ensure that the estimated results are not spurious (that is, the classical assumptions of the ordinary least squares (OLSs) were not violated); post-estimation or robustness check was carried out with the use of heteroscedasticity, serial or auto-correlation and multicollinearity. Heteroscedasticity test helps to examine whether the variations in the residuals of the model are constant over time or otherwise; the null hypothesis states that the standard errors of the model are constant over time. This test was carried out using Breusch-Pagan/Cook-Weisberg test and the result of the heteroscedasticity with $p$-value of approximately 0.49 , which is greater than the $5 \%$ level of baseline significance for the study, indicates that there is no incidence of heteroscedasticity. That is, the residuals of the model are constant over time, thus the study accepts the null hypothesis.

In addition, the serial correlation test was carried out to determine the existence of autocorrelation among the residuals and the coefficients of the model. Autocorrelation problem causes the standard errors of the coefficient to be smaller than their actual value and the coefficient of determination (R-squared) to be higher than normal. The null hypothesis of the test states that there is no serial correlation. Using Wooldridge test, the result of with $p$-value 0.0000 , which is less than the baseline significant level of $5 \%$, which indicates that there is serial correlation problem in the model. Therefore, the study rejects the null hypothesis.

Table 5 Pairwise correlation matrix

\begin{tabular}{|c|c|c|c|c|c|}
\hline Variables & $\begin{array}{c}\text { Human } \\
\text { development }\end{array}$ & $\begin{array}{c}\text { Foreign direct } \\
\text { investment }\end{array}$ & $\begin{array}{c}\text { Foreign direct } \\
\text { investment }\end{array}$ & Trade agreement & Trade openness \\
\hline Human development & 1.00 & & & & \\
\hline $\begin{array}{l}\text { Foreign direct } \\
\text { investment }\end{array}$ & 0.01 & 1.00 & & & \\
\hline $\begin{array}{l}\text { Foreign direct } \\
\text { investment }\end{array}$ & 0.38 & -0.32 & 1.00 & & \\
\hline Trade agreement & 0.23 & -0.16 & 0.45 & 1.00 & \\
\hline Trade openness & 0.15 & -0.092 & 0.00 & 0.59 & 1.00 \\
\hline
\end{tabular}

Source: Computed by the Researchers, 2019

The third post-estimation test conducted was the test for multicollinearity. Multicollinearity is an economic problem that exists when the OLS assumption of a no perfect correlation between the independent variables within a model has been violated, 
because a high level of correlation exists among the independent variables, which produce unrealistic results. The pairwise correlation matrix was engaged to determine the presence of multicollinearity in the dataset as presented in Table 5.

Table 5 presents the correlation matrix for the variables in the model; the result shows that there is very little correlation among the variables in the model. According to Gujarati (2009), if the pairwise correlation between two variables exceeds 0.8 , this indicates a high level of multicollinearity. Therefore, the overall result of this model indicates the absence of multicollinearity.

\section{Summary and conclusion}

The motivation for this study stemmed from the benefits of trade agreement and economic integration to Africa. As countries integrate, it will enhance liberalisation of trade, which invariably stimulates the expansion of the market, investment and larger diffusion of technology. In addition, it creates more local job opportunities for people and acquires goods and services at a lower cost due to lowered tariffs.

The study employed the panel ordinary least squares (POLS), fixed and the random effects regression model to achieve its objective. The study engaged five major variables, which included economic development proxied by human development index as the dependent variable while the independent variables were FDI, gross fixed capital formation, trade agreement and trade openness. The result showed that a $1 \%$ increase in FDI has the potential of increasing economic development by $2 \%$ to $3 \%$, while gross fixed capital formation has a greater positive impact on the economy by increasing the level of development by $3 \%$ to $9 \%$. It was observed that trade openness has a negative effect on the East African countries which is believed to be the resultant effect of net import (import greater than export which means dumping). Therefore, based on the findings of the study, it recommends that trade agreement between East African countries and other regions of Africa should be promoted, and economic integration between European Union and African countries should be encouraged to attract FDI which will, in turn, boost the economic development of the sub-region.

\section{References}

Abbiss, C.R. and Laursen, P.B. (2008) 'Describing and understanding pacing strategies during athletic competition', Sports Medicine, Vol. 38, No. 3, pp.239-252.

Afolayan, O., Okodua, H., Matthew, O. and Osabohien, R. (2019) 'Reducing unemployment malaise in Nigeria: the role of electricity consumption and human capital', International Journal of Energy Economics and Policy, Vol. 9, No. 4, pp.63-73.

Ajayi, S.I. and Ndikumana, L. (2015) Scale, Causes and Effect of Capital Flight from Africa, Capital Flight from Africa: Causes, Effects and Policy Issues, Oxford University Press, Oxford, pp.1-11.

Barone, P.W., Baik, S., Heller, D.A. and Strano, M.S. (2005) 'Near-infrared optical sensors based on single-walled carbon nanotubes', Nature Materials, Vol. 4, No. 1, p.86.

Carbaugh, J.D. (2004) U.S. Patent No. 6,739,244, U.S. Patent and Trademark Office, Washington, DC. 
Castro, L., Kraus, C. and de la Manuel, R. (2004) Regional Trade Integration in East Africa: Trade and Revenue Impacts of the Planned East African Community Customs Union, African Region Working paper series No. 72, Retrieved from http://www.worldbank.org/afr/wps/index.htm

Collins, M. (1998) 'Economic integration in Southern Africa: challenges and prospects', Mizan Law Review, Vo. 8., No. 1, pp.299-332.

Ejemeyovwi, J.O., Osabuohien, E.S. and Osabohien, R. (2018) 'ICT investments, human capital development and institutions in ECOWAS', International Journal of Economics and Business Research, Vol. 15, No. 4, pp.463-474.

Esterhuysen, P. (Ed.) (1978) Africa A-Z Continental and Country Profiles, African Institute of South Africa, Pretoria, p.62.

Geda, A. and Kebret, H. (2008) Regional economic integration in Africa: a review of problems and prosper, acts with a case study of comesa', Journal of African Economies, Vol. 17, No. 3, pp.357-394.

Goyal, S., Sergi, B.S. and Esposito, M. (2018) 'Business development services for micro, small and medium enterprises-literature review of past trends and future directions', Review of Entrepreneurship, Management and Sustainable Development, Vol. 14, No. 3, pp.312-332.

Goyal, S., Sergi, B.S. and Kapoor, A. (2016) 'Evaluating the BDS providers and MSMEs: challenges and strategic actions', The European Journal of Development Research, Vol. 29, pp.725-744.

Gujarati, D.N. (2009) Basic Econometrics, 5th ed., McGraw Hill, New York.

Hailu, M.B. (2014) 'Regional economic integration in Africa: challenges and prospects', Mizan Law Review, Vol. 8, No. 2, pp.299-332.

Hamad, H.B. (2016) 'Neo-functionalism: relevancy for East African community political integration?', The Journal of Pan African Studies, Vol. 9, No. 7, pp.69-81.

Harsch, E. (2002) 'Making African integration a reality in african recovery', European Science Journal, Vol. 4, No. 3, pp.11-21.

Hoffman, S. (1966) Obstinate or obsolete? The fate of the nation-state and the case of Western Europe, 95 Daedalus, as cited by Finn Laursen (February 2008), "Theory and practice of regional integration", 8 Jean Monnet/Robert Schuman Paper Series 3, p.5.

Kawonishe, D. (2001) 'Is Globalisation exacerbating or alleviating poverty and underdevelopment in Africa?', African Journal of International Affairs and Development, Vol. 6, No. 2, pp.1-6.

Matthew, O.A., Ede, C., Osabohien, R., Ejemeyovwi, J., Ayanda, T. and Okunbor, J. (2018a) 'Interaction effect of tourism and foreign exchange earnings on economic growth in Nigeria', Global Business Review, Vol. 2, pp.1-16, DOI: 10.1177/0972150918812985.

Matthew, O., Ede, C., Osabohien, R., Ejemeyovwi, J., Fasina, F. and Akinpelumi, D. (2018b) 'Electricity consumption and human capital development in Nigeria: exploring the implications for economic growth', International Journal of Energy Economics and Policy, Vol. 8, No. 6, pp.8-15.

Matthew, O., Osabohien, R., Urhie, E., Ewetan, O., Adediran, O., Oduntan, E., and Olopade, C. (2019a) 'Agriculture as a stimulant for sustainable development in ECOWAS', Sustainability: the Journal of Record, Vol. 12, No. 4, pp.215-225.

Matthew, O., Osabohien, R., Olawande, T. and Urhie, E. (2019b) 'Manufacturing industries and construction emissions in Nigeria: examining the effects on health conditions', International Journal of Civil Engineering and Technology, Vol. 10, No. 1, pp.2401-2414.

Matthew, O.A., Miebaka-Ogan, T., Popoola, O., Olawande, T., Osabohien, R., Urhie, E., Adediran, O. and Ogunbiyi, T. (2019c) 'Electricity consumption, government expenditure and sustainable development in Nigeria: a co-integration approach', International Journal of Energy Economics and Policy, Vol. 9, No. 4, pp.74-80. 
Mevel, S. and Karingi, S. (2012) 'Deepening regional integration in Africa: a computable general equilibrium assessment of the establishment of a continental free trade area followed by a continental customs union', Selected paper for presentation at the 7th African Economic Conference, 30 October-2 November, 2012, University of Rwanda, Kigali, Rwanda, pp.11-24.

Mistry, P. (2000) 'The Royal African Society Africa's record of regional co-operation and integration', African Affairs, Vol. 99, No. 397, pp. 553-573.

Mold, A. and Mukwaya, R. (2016) 'Modelling the economic impact of the tripartite free trade area: Its implications for the economic geography of Southern, Eastern and Northern Africa', Journal of African Trade, Vol. 3, Nos. 1-2, pp.57-84.

Moravcsik, A-S.U. (2006) 'Reconciling theories of regional integration: a third-way approach', A paper presented at the Third Pan European Conference of European Consortium for Political Research Standing Group on EU Politics, September, Bilgi University, Istanbul, p.4.

Mutume, G. (2002) 'How to boost trade within Africa', Africa Recovery, Vol. 16, p.20.

Newman, J. and Clarke, J. (2009) Publics, Politics and Power: Remaking the Public in Public Services, Sage, http://oro.open.ac.uk/16218/4/2DA38EAB.pdf

Ngepah, N. and Udeagha, M.C. (2018) 'African regional trade agreements and intra-African trade', Journal of Economic Integration, Vol. 33, No. 1, pp.24-39.

Nye, J.S. (1963) 'Patterns and catalysts in regional integration', The University of Wisconsin Press Journals Division, Vol. 19, No. 4, pp.870-884.

Osabohien, R., Afolabi, A. and Godwin, A. (2018) 'An econometric analysis of food security and agricultural credit facilities in Nigeria', The Open Agriculture Journal, Vol. 12, pp.227-239.

Osabohien, R., Matthew, O., Gershon, O., Ogunbiyi, T. and Nwosu, E. (2019) 'Agriculture development, employment generation and poverty reduction in West Africa', The Open Agriculture Journal, Vol. 13, pp.82-89.

Osabuohien, E., Obiekwe, E., Urhie, E. and Osabohien, R. (2018) 'Inflation rate, exchange rate volatility and exchange rate pass-through nexus: the Nigerian experience', Journal of Applied Economic Sciences, Vol. XIII, Spring 2, No. 56, pp.574-585.

Osuma, G., Ikpefan, A., Osabohien, R., Ndigwe, C. and Nkwodimmah, P. (2018) 'Working capital management and bank performance: empirical research of ten deposit money banks in Nigeria', Banks and Bank Systems, Vol. 13, No. 2, pp.49-61.

Rivera-Batiz, L.A. and Romer, P.M. (1991) 'Economic integration and endogenous growth', The Quarterly Journal of Economics, Vol. 106, No. 2, pp.531-555.

Sachs, J. (2005) The End of Poverty: How we can Make it Happen in Our Lifetime, Penguin Publishers, UK.

Saygili, M., Peters, R. and Knebel, C. (2018) 'African continental free trade area: challenges and opportunities of tariff reductions', United Nations Conference on Trade and Development (UNCTAD), Research Paper No. 15, pp.1-23.

Tiruneh, E.A., Wamboye, E. and Sergi, B.S. (2016) 'Does productivity in Africa benefit from advanced countries' R\&D?', Technology Analysis \& Strategic Management, Vol. 29, No. 7, pp.1-14.

UNECA (2004) Assessing Regional Integration in Africa, Addis Ababa, p.9, Accessed from the internet on the 12th December, 2018.

Wamboye, E., Adekola, A. and Sergi, B.S. (2013) 'Economic growth and the role of foreign aid in selected African countries', Development, Vol. 56, No. 2, pp.155-171.

Wamboye, E., Adekola, A. and Sergi, B.S. (2016) 'ICTs and labour productivity growth in sub-Saharan Africa', International Labour Review, Vol. 155, No. 2, pp.231-252. 